Vol. 2, No. 2, Juli - Desember 2018

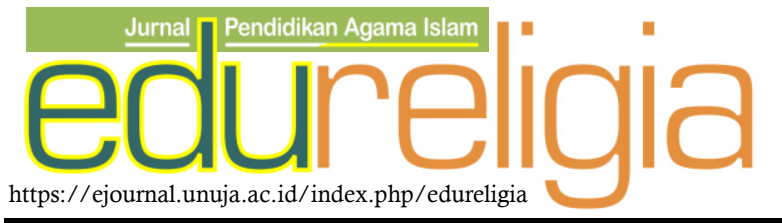

\title{
PRINSIP - PRINSIP PENGEMBANGAN KURIKULUM DALAM UPAYA MENINGKATKAN KUALITAS PEMBELAJARAN
}

\author{
Shofiyah $^{1}$ \\ Universitas Nurul Jadid Paiton Probolinggo
}

\begin{tabular}{l} 
Info Artikel \\
\hline Sejarah Artikel: \\
Diterima; Agustus 2018 \\
Disetujui; September \\
2018 \\
Dipublikasikan; Oktober \\
2018 \\
\\
\hline Keywords: \\
Principles, Curriculum \\
Development, Learning
\end{tabular}

Info Artikel

Diterima; Agustus 2018

Disetujui; September

Dipublikasikan; Oktober

\begin{abstract}
Education occupies a very strategic position in realizing the process of maturity and human thinking. Given the importance of education for human life, education must be carried out as well as possible. To achieve the educational goals, a curriculum is needed as one of the tools and guidelines in achieving educational goals. The curriculum is a device that is inseparable from the operation of education itself, because the preparation of the curriculum is spelled out from certain educational theories. This means that the curriculum is seen as a concrete plan in the application of educational theory. In the development of an educational curriculum must follow the principles of curriculum development that are in harmony with human nature and directed to achieve the ultimate goal of education. The curriculum should pay attention to the periodization of the development of students and maintain the needs of the community and their organizations not contradictory and not cause conflict. Effective curriculum and curriculum that pay attention to the level of development of students. Curriculum development is one of the efforts made to achieve educational goals, one of which is to improve the quality of learning
\end{abstract}

(C) 2018 Fakultas Agama Islam Universitas Nurul Jadid 


\section{PENDAHULUAN}

Pendidikan sangat penting dan tidak dapat dipisahkan dari kehidupan. Dengan pendidikan itu akan dapat memajukan budaya dan meningkatkan derajat bangsa di mata masyarakat internasional. Seperti dikatakan Daoed Joesoef, sebagaimana diungkapkan Soesilo, pendidikan adalah alat yang sangat menentukan untuk mencapai kemajuan di semua bidang mata pencaharian, dalam memilih dan membina kehidupan yang lebih baik, yang sesuai dengan kedudukan manusia (M.J. Susilo 2007, p. 13). Dalam hal ini kurikulum sebagai pedoman dalam pelaksanaan kegiatan belajar berarti bahwa dalam kurikulum terdapat panduan untuk interaksi antara guru dan siswa. Dengan begitu, kurikulum mempunyai fungsi sebagai "nafas atau inti" dari proses pendidikan di sekolah untuk memberdayakan siswa yang berpotensi (Tamami 2016, p. 3). Kurikulum adalah media yang menentukan terhadap keberhasilan proses pendidikan, dalam artian bahwa tanpa kurikulum yang baik dan sesuai akan sulit untuk mencapai tujuan pendidikan yang dicita-citakan (Yulianti, Hartatik 2016, p. 307). Untuk mempersiapkan hal itu, lembaga pendidikan tersebar di seluruh Indonesia, terutama lembaga pendidikan Islam di tingkat pusat, daerah terus melakukan berbagai upaya untuk meningkatkan kinerja semua komponen madrasah/sekolah agar memiliki persaingan yang kompetitif (Baharun 2016, p. 244). Dan salah satu program yang harus dilakukan adalah merencanakan pengembangan kurikulum yang dalam hal ini diupayakan untuk meningkatkan kualitas pembelajaran.

\section{PEMBAHASAN}

\section{Konsep Pengembangan Kurikulum dalam Pembelajaran}

1. Konsep Pengembangan Kurikulum

Kurikulum diartikan sebagai manhaj, yang merupakan cahaya, atau jalan ringan yang dilewati manusia di bidang kehidupannya. Sedangkan kurikulum dalam konteks pendidikan, berarti jalur cerah yang dilalui oleh guru bersama siswa untuk mengembangkan pengetahuan, keterampilan dan sikap serta nilai-nilai (Hasan Baharun 2017, p. 89-90). Sedangkan Menurut Taba dalam Nasution menafsirkan kurikulum sebagai "rencana pembelajaran", yang direncanakan untuk pembelajaran anakanak. Pandangan tradisional tentang kurikulum, merumuskan bahwa kurikulum adalah beberapa mata pelajaran yang harus diambil oleh siswa untuk mendapatkan ijazah (Lazwardi 2017, p. 101).

Kurikulum memiliki pemahaman yang sangat luas, mulai dari upaya terbatas untuk mempengaruhi siswa untuk belajar di dalam dan di luar kelas, hingga pemahaman yang luas di mana kurikulum juga mencakup fasilitas dan infrastruktur pendidikan, siswa dan bahkan anggota masyarakat yang harus melakukan proses pendidikan. diimplementasikan (Suradnya 2009, p. 162). Dalam makalah ini kurikulum diartikan sebagai referensi untuk melaksanakan pendidikan dalam rangka meningkatkan kualitas pembelajaran. Hal ini dimaksudkan untuk dapat menghasilkan sekolah yang berkualitas seiring dengan meningkatnya permintaan akan kualitas dan kualitas sekolah yang merupakan salah satu tujuan pendidikan.

Definisi paling umum dari kurikulum adalah seperangkat mata pelajaran yang akan diajarkan kepada siswa. Konsep kurikulum sebagai pengalaman belajar lebih baik menggambarkan situasi yang lebih akurat daripada konsep lain. Sekolah didirikan untuk mendidik siswa, yaitu bahwa mereka berkembang sesuai dengan jalur tertentu. Perkembangan ini hanya dapat dicapai melalui pengalaman belajar yang mereka peroleh. Kurikulum sebagai cetak biru untuk pendidikan harus mengarah pada penyediaan pengalaman belajar bagi siswa yang dirancang dengan baik dan diimplementasikan dengan benar. Kurikulum juga sering diartikan sebagai materi pelajaran atau materi pelajaran untuk peserta didik, atau rencana pelajaran. Baik itu rencana, dokumen, atau pedoman belajar, atau pengalaman belajar yang diadopsi oleh seseorang, akan mengarahkannya dalam melakukan kegiatan belajar (Lase 2018, p. 49-50). Kurikulum memiliki posisi yang sangat penting dalam seluruh proses pendidikan. Konsep kurikulum berkembang sesuai dengan perkembangan teori dan praktik pendidikan, juga bervariasi sesuai dengan alur atau teori pendidikan. Oleh karena itu, pengalaman belajar yang disusun di dalam kurikulum harus sesuai dengan kebutuhan masyarakat (Fitrah 2015, p. 42-50).

Dalam konteks pengembangan kurikulum, ini adalah proses perencanaan kurikulum untuk menbuahkan rencana kurikulum yang luas dan jelas. Proses tersebut terkait dengan pemilihan dan pengorganisasian berbagai komponen dari situasi belajar-mengajar, termasuk penetapan jadwal untuk memanaje kurikulum dan 
menentukan tujuan, mata pelajaran, aktivitas, sumber dan ukuran pengembangan kurikulum yang mengacu pada penciptaan sumber daya dan rencana unit, serta jalur pelajaran kurikulum ganda lainnya, untuk memfasilitasi proses pembelajaran (Yu'timaalahuyatazaka 2016, p. 140).

Pengembangan kurikulum merupakan istilah yang komprehensif, yang meliputi perencanaan, implementasi, dan evaluasi. Perencanaan kurikulum yaitu langkah terdepan dalam membangun kurikulum ketika pekerja kurikulum membuat keputusan dan mengambil tindakan untuk menghasilkan rencana yang akan dipakai oleh guru dan siswa. Penerapan kurikulum atau yang biasa disebut implementasi kurikulum berupaya memindahkan perencanaan kurikulum ke dalam tindakan operasional. Evaluasi kurikulum adalah tahap akhir pengembangan kurikulum untuk melihat sejauh mana hasil pembelajaran, tingkat pencapaian program yang direncanakan, dan hasil dari kurikulum tersebut. Pengembangan kurikulum bukan hanya melibatkan orang-orang yang berhubungan langsung dengan dunia pendidikan, tetapi juga melibatkan banyak individu, seperti politisi, wirausahawan, orang tua siswa, dan elemen masyarakat lainnya yang merasa tertarik dengan pendidikan. Prinsip-prinsip yang akan digunakan dalam kegiatan pengembangan kurikulum pada intinya adalah aturan atau undang-undang yang akan menginspirasi kurikulum (Kamal 2014, p. 230-231).

Melihat uraian di atas, jelas bahwa keberadaan kurikulum sangat diperlukan. Kurikulum adalah komponen terpenting di samping guru dan fasilitas. Dengan kurikulum, akan ada gambaran yang jelas tentang tujuan yang ingin dicapai, materi pembelajaran yang akan diproses, program pembelajaran yang akan dilakukan, dan kegiatan pembelajaran yang harus dilaksanakan untuk mencapai tujuan. Kurikulum memberikan bimbingan kepada guru untuk menyusun dan menerapkan program pembelajaran. Tinjauan tentang kualitas output yang tinggi juga dapat diperkirakan dari kurikulum yang diterapkan (J. Susilo 2016, p. 46).

\section{Konsep Pembelajaran}

Istilah belajar adalah pengembangan dari istilah mengajar dan istilah mengajar dan belajar, sebagai terjemahan dari istilah mengajar yang terdiri dari dua kata, yaitu belajar dan mengajar. Belajar yaitu proses yang ditandai oleh perubahan dalam diri seseorang. Perubahan sebagai hasil dari suatu proses pembelajaran dapat ditunjukkan dalam pelbagai bentuk seperti mengubah pengetahuan, keterampilan, dan kemampuan, kekuatan reaksi, dan penerimaan individu. Sementara Mengajar adalah mengkondisikan suatu lingkungan sehingga kegiatan belajar diciptakan, dengan kata lain mengajar adalah belajar siswa. Dari kedua istilah tersebut, dapat ditarik kesimpulan untuk definisi pembelajaran, yaitu interaksi antara peserta didik (learning / learning) dan pendidik (teaching / teaching) melalui penggunaan berbagai media / sumber belajar. Sejalan dengan itu, dalam undang-undang No. 20 tahun 2003 tentang Sistem Pendidikan Nasional pasal 1 ayat (20) menyatakan bahwa belajar adalah proses interaksi siswa dengan pendidik dan sumber belajar dalam lingkungan belajar. Istilah pembelajaran dalam garis besar dapat didefinisikan sebagai proses interaksi antara komponen-komponen sistem pembelajaran dengan tujuan mencapai hasil pembelajaran. Ini berarti bahwa pembelajaran adalah proses transaksional (timbal balik timbal balik) antara komponen-komponen sistem pembelajaran, yaitu pendidik, siswa, bahan ajar, media, alat, prosedur dan proses pembelajaran guna mencapai perubahan komprehensif pada siswa.

Perubahan komprehensif berarti perubahan mendalam dan esensial dalam perilaku, sikap, pengetahuan, dan kemampuan makna pada siswa yang dapat berguna untuk menyelesaikan tugas/kewajiban dalam kehidupan mereka, sehingga melalui kegiatan pembelajaran yang berkelanjutan, semua kebutuhan hidup siswa ini sebagai pribadi. manusia akan terpenuhi. Belajar adalah proses sistematis di mana semua komponen, termasuk guru, siswa, materi dan lingkungan belajar adalah komponen penting untuk keberhasilan pembelajaran.

Belajar sebagai suatu sistem menggunakan pendekatan sistem dalam desain pembelajaran. Mengingat sistem, semua komponen yang terlibat dalam pembelajaran saling berinteraksi untuk mencapai tujuan pembelajaran. Berdasarkan penjelasan di atas, sejumlah kata kunci dari istilah pembelajaran dapat ditarik, yaitu pembelajaran adalah proses yang melibatkan interaksi antara instruktur dan siswa, baik secara langsung maupun melalui penggunaan berbagai media pembelajaran, dan diambil untuk mendapatkan perubahan dalam perilaku secara keseluruhan (Fujiawati 2016, p. 20-22). 
Landasan Pengembangan Kurikulum dalam Meningkatkan Kuailitas Pembelajaran

Pengembangan kurikulum adalah proses yang menentukan bagaimana kurikulum akan dilaksanakan. Agar pengembangan kurikulum berhasil sesuai dengan apa yang diinginkan, maka pengembangan kurikulum membutuhkan dasar pengembangan kurikulum. Pengembangan kurikulum menurut Dimyati dan Mudjiono mengacu pada tiga elemen, yaitu 1) nilai-nilai dasar yang merupakan filosofi dalam pendidikan manusia yang lengkap, 2) fakta empiris yang tercermin dalam implementasi kurikulum, baik berdasarkan penilaian kurikulum, studi, dan survei lain, dan 3) dasar teoretis yang merupakan arah pengembangan dan kerangka kerja penyorotan.

Lebih lanjut Dimyati dan Mudjiono menyatakan bahwa dasar pengembangan kurikulum meliputi:

\section{Landasan Filosofis}

Dalam filsafat pendidikan beberapa sekolah filsafat dikenal, yaitu perkembangan, esensialisme, perenialisme, rekonstruksionisme dan eksistensialisme. Setiap aliran memiliki latar belakang dan konsep yang berbeda (Bahri 2011, p. 22-23). Aliran perkembangan adalah sekolah yang memprioritaskan kebebasan dan menentang semua bentuk otoritarianisme dan absolutisme. Berbeda dengan aliran esensialisme yang berupaya menyatukan konflik antara konsepsi idealisme dan realisme. Perennialisme muncul sebagai sekolah "progresif" yang mundur ke masa lalu ke abad pertengahan. Sedangkan aliran rekonstruksionisme adalah aliran yang melihat semua gejala yang berasal dari keberadaan, yaitu cara manusia berada di dunia yang berbeda dari keberadaan materi.

Sedangkan eksistensialisme adalah aliran yang berfokus pada pengalaman individu. Dalam pengembangan kurikulum, tentunya harus didasarkan pada sekolah filosofis tertentu, langkah ini akan memberi nuansa pada konsep dan implementasi kurikulum yang dikembangkan. Aliran Filsafat Perennialisme, Esensialisme, Eksistensialisme adalah filosofi yang mendasari pengembangan model kurikulum subjek-akademik. Padahal, filosofi progresivisme memberikan dasar untuk pengembangan model kurikulum pendidikan pribadi. Sementara itu, filsafat rekonstruktivisme secara luas diterapkan dalam pengembangan model kurikulum interaksional. Setiap aliran filsafat harus memiliki kelemahan dan kelebihannya sendiri. Oleh karena itu, dalam praktik pengembangan kurikulum, penerapan aliran filsafat cenderung dilakukan secara efektif untuk lebih berkompromi dan mengakomodasi berbagai minat terkait dengan pendidikan. Meski begitu pada saat ini, di beberapa negara dan terutama di Indonesia, tampaknya ada pergeseran dalam dasar pengembangan kurikulum, yang lebih fokus pada filosofi rekonstruktivisme.

Landasan filosofis pendidikan merupakan cabang dari filsafat yang mengkaji tentang apa, bagaimana, dan mengapa pendidikan. Bagi Seorang guru yang mempelajari dan memahami landasan filosofis pendidikan akan melakukan berbagai upaya untuk ketercapaian proses pembelajaran yang ia lakukan. Bagi pendidik yang peka mengenai filosofis pendidikan akan memahami tujuan ia mendidik. Sehingga, kecermatan dari seorang pendidik untuk memikirkan cara peserta didik belajar, dengan metode apa peserta didik belajar, dan sejauhmana keterlibatan siswa dalam proses pembelajaran apakah anak pasif atau katif, serta sejauhmana keberhasilan siswa dalam melaksanakan pembelajaran, dan sebagainya.

Pendidikan ada dan ada dalam kehidupan masyarakat sehingga apa yang diinginkan oleh masyarakat untuk dilestarikan dilaksanakan melalui pendidikan. Semua kemauan yang dimiliki oleh masyarakat adalah sumber nilai yang memberi arah pada pendidikan. Dengan demikian pandangan dan wawasan yang ada dalam masyarakat adalah pandangan dan wawasan dalam pendidikan atau dapat dikatakan bahwa filsafat yang hidup dalam masyarakat adalah landasan filosofis untuk implementasi pendidikan. Filsafat adalah studi tentang sifat realitas, sifat ilmu pengetahuan, sifat sistem nilai, sifat nilai kebaikan, sifat keindahan, dan sifat pikiran. Oleh karena itu, landasan filosofis pengembangan kurikulum adalah sifat realitas, sains, sistem nilai, nilai kebaikan, keindahan, dan sifat pemikiran yang ada di masyarakat. Dalam hal ini yayasan ini terkandung dalam proses pembelajaran (Rohinah 2019, p. 3)

\section{Landasan Psikologis}

Syafruddin Nurdin mengatakan, pada dasarnya pendidikan tidak dapat dipisahkan dari unsur-unsur psikologi, karena pendidikan adalah tentang perilaku manusia itu sendiri, mendidik berarti mengubah perilaku anak menuju kedewasaan. Karena 
itu, proses belajar mengajar selalu dikaitkan dengan teori perubahan perilaku anak. Beberapa teori perilaku termasuk behaviorisme, psikologi kekuatan, perkembangan kognitif, teori lapangan (teori Gastalt) dan teori kepribadian. Ada dua bidang psikologi yang mendasari pengembangan kurikulum, psikologi perkembangan, dan psikologi pembelajaran. Psikologi perkembangan mempelajari perilaku individu mengenai perkembangannya (Nurdin 2005, p. 37).

Dalam psikologi perkembangan, dipelajari tentang sifat perkembangan, tahap perkembangan, aspek perkembangan, tugas pengembangan individu, dan hal-hal lain yang berkaitan dengan pengembangan individu, di mana semuanya dapat digunakan sebagai bahan pertimbangan yang mendasari pengembangan kurikulum. Belajar psikologi adalah studi tentang perilaku individu dalam konteks pembelajaran. Belajar Psikologi meneliti sifat belajar dan teori-teori belajar, serta berbagai aspek perilaku individu lainnya dalam belajar, yang dapat dipertimbangkan serta pengembangan kurikulum yang mendasarinya.

Dari uraian di atas, setidaknya dapat dipahami, bahwa fondasi psikologis dalam pengembangan kurikulum menempati posisi dan peran penting. Anak adalah target dan sekaligus target kurikulum, maka pertimbangan psikologis menjadi sesuatu yang penting dalam perencanaan dan penyusunan kurikulum, sehingga dimungkinkan untuk mendapatkan hasil yang maksimal.

\section{Landasan Sosial, Budaya, dan Agama}

Realitas sosial, budaya dan agama yang ada di masyarakat adalah bahan untuk studi pengembangan kurikulum untuk digunakan sebagai dasar untuk pengembangan kurikulum. Kebersamaan individu dalam masyarakat terikat dan terikat oleh nilai-nilai yang menjadi dasar kehidupan dalam interaksi di antara mereka. Nilai-nilai yang perlu dipertahankan dan dihormati di masyarakat termasuk nilai-nilai agama dan sosial-budaya. Nilai-nilai agama terkait dengan kepercayaan publik terhadap ajaran agama, oleh karena itu mereka umumnya bertahan lama. Azas Sosiologis Indonesia memiliki kebudayaan yang sangat heterogen di tiap daerah dan masyarakatnya. Oleh karena itu, dalam pengembangan kurikulum masyarakat memiliki peran yang sangat penting, sehingga asas sosiologis dijadian salah satu asas yang mempengaruhi terhadap pengembangan kurikulum. Namun Dalam perkembangannya asa ini juga tidak boleh mendominasi dari asas asas yang lain karena kan mengakibatkan kurikulum akan berpusat pada masyarakatatau yang kita kenal dengan bahasa "society centered curriculum ". Damun patut disyukuri di negara kita belum mengarah pada kurikulum itu artinya kurikulum masih terpusat pada sekolah, namun meskipun kurikulum tetap terpusat disekolah pada kenyataan dimasyarakat sudah dietrapkan dalam bentuk kurikulum muatan lokal yang disesuaikan dengan daerah masing-masing. Dengan dijadikannya asas ini sebagai landasan pengembangan kurikulum diharapkan lulusan yang bekerja nantinya dapat memnuhi kebutuhan sesuai yang diharpkan oleh masyrakat pada umumnya.

Nilai-nilai sosial dan budaya masyarakat berasal dari karya akal manusia, sehingga dalam menerima, menyebarkan, melestarikan, dan melepaskannya manusia menggunakan akal budi mereka. Dengan demikian jika ada nilai sosial-budaya yang tidak diterima / tidak sesuai dengan akalnya, ia akan dibebaskan. Karena itu nilai sosial dan budaya lebih bersifat sementara jika dibandingkan dengan agama. Untuk melaksanakan penerimaan, penyebaran, pelestarian, atau penolakan dan pelepasan nilai-nilai sosial-budaya-agama, masyarakat menggunakan pendidikan yang dirancang melalui kurikulum.

Kurikulum dapat dilihat sebagai desain pendidikan. Sebagai desain, kurikulum menentukan implementasi dan hasil pendidikan. Dapat dimengerti bahwa pendidikan adalah upaya sadar untuk mempersiapkan siswa untuk terjun ke masyarakat. Pendidikan tidak hanya untuk pendidikan tetapi juga lebih penting untuk memberikan pengetahuan, keterampilan dan nilai-nilai untuk hidup, bekerja dan mencapai perkembangan lebih lanjut di masyarakat. Siswa berasal dari komunitas, mendapatkan pendidikan formal dan informal di dalam komunitas dan diarahkan untuk kehidupan masyarakat juga. Kehidupan masyarakat, dengan semua karakteristik dan kekayaan budayanya, menjadi dasar dan sekaligus referensi untuk pendidikan.

Kami tidak berharap munculnya manusia yang terasing dari komunitas mereka, melainkan melalui pendidikan diharapkan bahwa kelahiran manusia dapat lebih memahami dan mampu membangun kehidupan masyarakat mereka. Oleh karena itu, tujuan, isi, dan proses pendidikan harus 
disesuaikan dengan kebutuhan, kondisi, karakteristik, kekayaan dan perkembangan yang ada di masyarakat. Nana Syaodih Sukmadinata berpendapat, bahwa melalui pendidikan manusia mengenali peradaban masa lalu, berpartisipasi dalam peradaban saat ini dan menjadikan peradaban masa depan (Raharjo 2018, p. 132).

Dengan demikian, kurikulum yang dikembangkan harus mempertimbangkan, merespons dan didasarkan pada perkembangan sosial-budaya dalam masyarakat, baik dalam konteks lokal, nasional dan global. Setiap lingkungan komunitas memiliki sistem sosial-budaya sendiri yang mengatur pola kehidupan dan pola hubungan antara anggota masyarakat. Salah satu aspek penting dari sistem sosialbudaya adalah urutan nilai-nilai yang mengatur cara hidup dan perilaku warga negara. Nilai-nilai ini dapat bersumber dari agama, budaya, politik atau aspek kehidupan lainnya. Sejalan dengan perkembangan masyarakat, nilai-nilai yang ada di masyarakat juga berkembang sehingga mengharuskan setiap warga negara untuk melakukan perubahan dan penyesuaian dengan tuntutan zaman.

4. Landasan Ilmu Pengetahuan, Teknologi, dan Seni

Awalnya ilmu pengetahuan dan teknologi (IPTEK) yang dimiliki manusia masih relatif sederhana, namun sejak abad pertengahan mengalami perkembangan yang pesat. Berbagai penemuan baru terus berlangsung hingga saat ini. Dapat dipastikan, bahwa masa yang akan datang penemuan tersebut semakin berkembang. Seiring perkembangan akal manusia yang telah mampu menjangkau hal hal yang sebelumnya merupakan sesuatu tidak mungkin. Sebagai ilustrasi, pada zaman dahulu kala, mungkin orang akan menganggap mustahil kalau manusia bisa menginjakkan kaki di permukaan Bulan, tetapi berkat kemajuan dan perkembangan IPTEK pada pertengahan abad ke-20, pesawat Apollo 11 berhasil mendarat di bulan dan Neil Amstrong merupakan orang pertama yang berhasil menginjakkan kaki di bulan.

Kemajuan pesat dalam bidang informasi dan teknologi dalam dua dekade terakhir telah mempengaruhi peradaban manusia di luar jangkauan pemikiran manusia sebelumnya. Pengaruh ini dapat dilihat pada pergeseran tatanan sosial, ekonomi dan politik yang membutuhkan keseimbangan baru antara nilai-nilai, pemikiran dan cara hidup yang berlaku untuk konteks global dan lokal. Selain itu, di zaman pengetahuan ini, orang yang berpengetahuan luas dibutuhkan melalui pembelajaran seumur hidup dengan standar kualitas tinggi.

Sifat pengetahuan dan keterampilan yang harus dikuasai oleh masyarakat sangat beragam dan canggih, sehingga diperlukan kurikulum yang disertai dengan kemampuan meta-kognisi dan kompetensi untuk berpikir dan cara belajar (learning to learning) dalam mengakses, memilih dan menilai pengetahuan, dan mengatasi situasi ambigu dan antisipatif terhadap ketidakpastian. Perkembangan di bidang sains dan teknologi, terutama di bidang transportasi dan komunikasi telah mampu mengubah tatanan kehidupan manusia. Oleh karena itu, kurikulum harus dapat mengakomodasi dan mengantisipasi laju perkembangan ilmu pengetahuan dan teknologi, sehingga siswa dapat menyeimbangkan dan secara bersamaan mengembangkan ilmu pengetahuan dan teknologi untuk memberi manfaat dan mempertahankan kehidupan manusia (Pambudi 2017).

Pendidikan adalah upaya untuk mempersiapkan siswa menghadapi perubahan yang semakin pesat, termasuk perubahan dalam sains, teknologi, dan seni (sains dan teknologi). Sukmadinata mengatakan bahwa pengembangan ilmu pengetahuan dan teknologi secara langsung akan menjadi konten / materi pendidikan, sementara secara tidak langsung memberikan tugas kepada pendidikan untuk melengkapi masyarakat dengan kemampuan untuk memecahkan masalah yang dihadapi sebagai pengaruh dari pengembangan ilmu pengetahuan dan teknologi. Selain itu, pengembangan ilmu pengetahuan dan teknologi juga digunakan untuk menyelesaikan masalah pendidikan.

Setiap yayasan tentu memiliki kontribusi penting untuk pengembangan kurikulum pendidikan. Basis filosofis berperan dalam merumuskan tujuan pendidikan. Sedangkan dasar psikologis memberikan gambaran umum tentang konten, proses dan evaluasi pendidikan. Adapun dasar sosial-budaya, itu memberikan ide tentang tujuan dan isi pendidikan. Sedangkan basis teknologinya, memberikan gambaran umum tentang konten dan proses pendidikan. 
Prinsip Pengembangan Kurikulum dalam Meningkatkan Kualitas Pembelajaran Pengembangan kurikulum menggunakan prinsip-prinsip yang telah berkembang dalam kehidupan sehari-hari atau justru menciptakan prinsip-prinsip baru. Oleh karena itu, dalam implementasi kurikulum di lembaga pendidikan sangat dimungkinkan untuk menggunakan prinsip yang berbeda dari kurikulum yang digunakan di lembaga pendidikan lain, sehingga akan ada banyak prinsip yang digunakan dalam pengembangan kurikulum (Fitroh 2011, p. 1-7).

Sukmadinata menyatakan prinsip pengembangan kurikulum yang terbagi menjadi dua jenis, yaitu prinsip umum dan prinsip spesifik. Prinsip umum pengembangan kurikulum adalah relevansi, fleksibilitas, kontinuitas, kepraktisan dan efektivitas. Prinsip-prinsip ini adalah lanskap yang kuat untuk mewujudkan kurikulum yang sesuai dengan kebutuhan siswa, guru, dan masyarakat. Prinsip khusus pengembangan kurikulum adalah berkaitan dengan tujuan pendidikan, prinsip yang berkaitan dengan pemilihan konten pendidikan, prinsip yang berkaitan dengan pemilihan proses belajar mengajar, prinsip yang berkaitan dengan pemilihan media dan alat belajar, dan prinsip yang berkaitan dengan pemilihan kegiatan penilaian.

Hal yang sama dinyatakan oleh Hernawan di Sudrajat menyarankan lima prinsip dalam pengembangan kurikulum, yaitu:

\section{Prinsip relevansi}

Secara internal, kurikulum memiliki relevansi antara komponen kurikulum (tujuan, bahan, strategi, organisasi, dan evaluasi). Sedangkan secara eksternal komponen itu memiliki relevansi dengan tuntutan sains dan teknologi (relevansi epistemologis), tuntutan dan potensi siswa (relevansi psikologis), serta tuntutan dan kebutuhan pengembangan masyarakat (relevansi sosiologis), Maka dalam membuat kurikulum harus memperhatikan kebutuhan lingkungan masyarakat dan siswa di sekitarnya, sehingga nantinya akan bermanfaat bagi siswa untuk berkompetisi di dunia kerja yang akan datang. Dalm realitanya prinsip diatas memang harus betul betul di perhatikan karena akan berpengaruh terhadap mutu pendidikan. Dan yang tidak kalah penting harus sesuai dengan perkembangan teknologi sehingga mereka selaras dalam upaya membangun negara (Asmariani 2014, p. 60).

\section{Prinsip fleksibilitas}

Pengembangan kurikulum berupaya agar hasilnya fleksibel, fleksibel, dan fleksibel dalam implementasinya, memungkinkan penyesuaian berdasarkan situasi dan kondisi tempat dan waktu yang selalu berkembang, serta kemampuan dan latar belakang siswa, peran kurikulum disini sangat penting terhadap perkembangan siswa untuk itu prinsip fleksibel ini harus benar benar diperhatikan sebagai penunjang untuk peningkatan mutu pendidikan.

Dalam prinsip fleksibilitas ini dimaksudkan bahwa, kurikulum harus memiliki fleksibilitas. Kurikulum yang baik adalah kurikulum yang berisi hal-hal yang solid, tetapi dalam implementasinya dimungkinkan untuk menyesuaikan penyesuaian berdasarkan kondisi regional. Waktu dan kemampuan serta latar belakang anak. Kurikulum ini mempersiapkan anakanak untuk saat ini dan masa depan. Kurikulum tetap fleksibel di mana saja, bahkan untuk anak-anak yang memiliki latar belakang dan kemampuan yang berbeda, pengembangan kurikulum masih bisa dilakukan

Kurikulum harus menyediakan ruang untuk memberikan kebebasan bagi pendidik untuk mengembangkan program pembelajaran. Pendidik dalam hal ini memiliki kewenangan dalam mengembangkan kurikulum yang sesuai dengan minat, kebutuhan siswa dan kebutuhan bidang lingkungan mereka (Mansur 2016, p. 3).

\section{Prinsip kontinuitas}

Yakni adanya kesinambungan dalam kurikulum, baik secara vertikal, maupun secara horizontal. Pengalaman belajar yang disediakan kurikulum harus memperhatikan kesinambungan, baik yang di dalam tingkat kelas, antarjenjang pendidikan, maupun antara jenjang pendidikan dan jenis pekerjaan.

Makna kontinuitas disini adalah berhubungan, yaitu adanya nilai keterkaitan antara kurikulum dari berbagai tingkat pendidikan. Sehingga tidak terjadi pengulangan atau disharmonisasi bahan pembelajaran yang berakibat jenuh atau membosankan baik yang mengajarkan (guru) maupun yang belajar (peserta didik). Selain berhubungan dengan tingkat pendidikan, kurikulum juga diharuskan berhubungan dengan berbagai studi, agar antara satu studi dapat melengkapi studi lainnya. Sedangkan fleksibilitas adalah kurikulum yang dikembangkan tidak kaku dan memberikan 
kebebasan kepada guru maupun peserta didik dalam memilih program atau bahan pembelajaran, sehingga tidak ada unsur paksaan dalam menempuh program pembelajaran. pembelajaran (Zainab 2017, p. 366).

\section{Prinsip efisiensi}

Peran kurikulum dalam ranah pendidikan adalah sangat penting dan bahkan vital dalam proses pembelajaran, ia mencakup segala hal dalam perencanaan pembelajaran agar lebih optimal dan efektif. Dewasa ini, dunia revolusi industri menawarkan berbagai macam perkembangan kurikulum yang dilahirkan oleh para ahli dari dunia barat. Salah satu pengembangan kurikulum yang dipakai oleh pemerintah Indonesia untuk mecapai sebuah cita-cita bangsa yaitu mengoptimalkan kecerdasan anak-anak generasi penerus bangsa untuk memilki akhlaq mulia dan berbudi pekerti yang luhur. Efisiensi adalah salah satu prinsip yang perlu diperhatikan dalam mengembangkan kurikulum, sehingga apa yang telah direncanakan sesuai dengan tujuan yang ingin dicapai. Jika sebuah program pembelajaran dapat diadakan satu bulan pada satu waktu dan memenuhi semua tujuan yang ditetapkan, itu bukan halangan. Sehingga siswa dapat mengimplementasikan program pembelajaran lain karena upaya itu diperlukan agar dalam pengembangan kurikulum dapat memanfaatkan sumber daya pendidikan yang ada secara optimal, cermat, dan tepat sehingga hasilnya memadai.

\section{Prinsip efektivitas}

Mengembangkan

kurikulum pendidikan perlu mempertimbangkan prinsip efektivitas, yang dimaksud dengan efektivitas di sini adalah sejauh mana rencana program pembelajaran dicapai atau diimplementasikan. Dalam prinsip ini ada dua aspek yang perlu diperhatikan, yaitu: efektivitas mengajar guru dan efektivitas belajar siswa. Dalam aspek mengajar guru, jika masih kurang efektif dalam mengajar bahan ajar atau program, maka itu menjadi bahan dalam mengembangkan kurikulum di masa depan, yaitu dengan mengadakan pelatihan, workshop dan lain-lain. Sedangkan pada aspek efektivitas belajar siswa, perlu dikembangkan kurikulum yang terkait dengan metodologi pembelajaran sehingga apa yang sudah direncanakan dapat tercapai dengan metode yang relevan dengan materi atau materi pembelajaran.
Oleh karena itu ada upaya dalam upaya membuat kegiatan pengembangan kurikulum mencapai tujuan tanpa kegiatan yang berlebihan, baik secara kualitas maupun kuantitas. Dalam implementasinya dalam proses pembelajaran adalah bagaimana tujuan pengembangan kurikulum ini dapat meningkatkan kualitas pembelajaran yang diharapkan oleh semua pihak, terutama efektivitas pembelajaran di kelas.

\section{KESIMPULAN}

Pengembangan kurikulum adalah istilah yang komprehensif, yang meliputi perencanaan, implementasi, dan evaluasi. Perencanaan kurikulum adalah langkah pertama dalam membangun kurikulum ketika pekerja kurikulum membuat keputusan dan mengambil tindakan untuk menghasilkan rencana yang akan digunakan oleh guru dan siswa. Penerapan kurikulum atau yang biasa disebut implementasi kurikulum berupaya mentransfer perencanaan kurikulum ke dalam tindakan operasional.

Oleh karena itu strategi pembelajaran dalam pendidikan sekolah harus diberikan dasar pertama dengan menginternalisasi sosiologi kritis, inovasi, kreativitas, dan mentalitas. Ini tidak berhenti di yayasan, tetapi juga berusaha menembus kurikulum yang ada dalam pendidikan sekolah. Selain itu, juga mengubah strategi pembelajaran yang telah didasarkan pada konsep pandangan reproduktif belajar menjadi pandangan pembelajaran yang konstruktif. Konsep ini pada dasarnya dibangun tanpa merusak fondasi yang sudah baik dalam proses belajar mengajar sejauh ini.

Agar pengembangan kurikulum berhasil sesuai dengan apa yang diinginkan, maka pengembangan kurikulum membutuhkan dasar pengembangan kurikulum. fondasi pengembangan kurikulum meliputi: fondasi filosofis, fondasi sosial, budaya dan agama, fondasi sains, teknologi, dan seni, fondasi kebutuhan masyarakat, dan fondasi pengembangan masyarakat. Prinsip umum pengembangan kurikulum adalah relevansi, fleksibilitas, kesinambungan, kepraktisan dan efektivitas. Prinsip khusus pengembangan kurikulum adalah berkaitan dengan tujuan pendidikan, prinsip yang berkaitan dengan pemilihan konten pendidikan, prinsip yang berkaitan dengan pemilihan proses belajar mengajar, prinsip yang berkaitan dengan pemilihan media dan alat belajar, dan prinsip yang 
berkaitan dengan pemilihan kegiatan penilaian.

\section{DAFTAR PUSTAKA}

Asmariani, MA. 2014. "Prinsip-Prinsip Pengembangan Kurikulum Dalam Perspektif Islam." Jurnal AL-AFKAR III(II): 60 .

Baharun, Hasan. 2016. "Manajemen Kinerja Dalam Meningkatkan Competitive Advantage Pada Lembaga Pendidikan Islam." Jurnal at-Tajdid 5(2): 244.

Bahri, Syamsul. 2011. "Pengembangan Kurikulum Dasar Dan Tujuannya." Jurnal Ilmiah Islam Futura XI(1): 22-23.

Fitrah, M. 2015. "Peta Konsep Prinsip Relevansi Dalam Arah Pengembangan Kurikulum Matematika: Kajian Perspektif Pengembangan Kurikulum." Jurnal Sainsmat IV(1): 42-50.

Fitroh. 2011. "Pengembangan Kurikulum Berbasis Kompetensi Dan Strategi Pencapaian." 4(2): 1-7.

Fujiawati, Fuja Siti. 2016. "Pemahaman Konsep Kurikulum Dan Pembelajaran Dengan Peta Konsep Bagi Mahasiswa Pendidikan Seni." 1(1): 20-22.

Hasan Baharun, DKK. 2017. Pengembangan Kurikulim: Teori Dan Praktik. Cetakan I. ed. Zamroni. Probolinggo: Pustaka Nurja.

Kamal, Mustofa. 2014. "Model Pengembangan Kurikulum Dan Strategi Pembelajaran Berbasis Sosiologi Kritis, Kreativitas, Dan Mentalitas." Jurnal Madaniyah 7(2): 230-31.

Lase, Famahato. 2018. "Dasar Pengembangan Kurikulum Menjadi Pengalaman Belajar." Jurnal PG-PAUD STKIP Pahlawan Tuanku Tambusai 3(1): 49-50.

Lazwardi, Dedi. 2017. "Manajemen Kurikulum Sebagai Pengembangan Tujuan Pendidikan." Kependidikan Islam 4(1): 101.

Mansur, Rosichin. 2016. "Pengembangan Kurikulum Pendidikan Agama Islam Multikultural (Suatu Prinsip-Prinsip Pengembangan)." Jurnal Ilmiah Vicratina 10(2): 3 .

Nurdin, Syafruddin. 2005. Guru Profesional Dan Implementasi Kurikulum. 3rd ed. Jakarta: Quantum Teaching.

Pambudi, Aris Fajar. 2017. "Prinsip Pengembangan Kurikulum." Power Point disajikan dalam seminar proposal yang dilakukan pada tanggal 25 Desember.

Raharjo, S. B. 2018. "Capaian Standar Nasional Pendidikan Sebagai Prediktor Achievement of National Standards of
Education As a Predictor." Jurnal Pendidikan dan Kebudayaan 3(2): 132.

Rohinah. 2019. "Filsafat Pendidikan Islam: Studi Filosofis Atau Tujuan Dan Metode Pendidikan Islam." Jurnal Pendidikan Islam II(2): 3.

Suradnya, I Made. 2009. "Pengembangan Kurikulum Pendidikan Dan Pelatihan Kepariwisataan Berkelanjutan." Jurnal Ilmu Pendidikan 16(3): 162.

Susilo, Jimat. 2016. "Pengembangan Kurikulum Bahasa Indonesia Bagi Penutur Asing." Jurnal Pendidikan Bahasa dan Sastra Indonesia 3(1): 46.

Susilo, M. Joko. 2007. "Pembodohan Siswa Tersistematis." In Jakarta: PINUS, 13.

Tamami, Badrut. 2016. "Pengembangan Kurikulum PAI Di SMK Zainul Hasan Kecamatan Balung Kabupaten Jember Tahun Pelajaran 2013/2014." Jurnal Penelitian IPTEKS: 3.

Yu'timaalahuyatazaka. 2016. "Model Pengembangan Kurikulum Hilda Taba Dan Identifikasinya Dalam Kurikulum Pendidikan Islam." Jurnal Manajemen Pendidikan Islam 4(2): 140.

Yulianti, Hartatik, dan Ninik Indawati. 2016. "Pengembangan Kurikulum PAUD (StudiKasus Di PAUD Citra KartiniDesa Senggreng

Kecamatan.Sumber Pucung - Kabupaten Malang) Yulianti,." Jurnal Inspirasi Pendidikan 12(2): 307.

Zainab, Nurul. 2017. "Prinsip - Prinsip Pengembangan Kurikulum Pendidikan Agama Islam Perspektif Islam." Jurnal Fenomena 16(2): 366. 